\title{
Consumers' intention to hire wedding planners: a study of selected cities in Northern India
}

\author{
Heena Kashyap* \\ Directorate of Education, \\ Government of NCT of Delhi, \\ Delhi, India \\ Email: heena.kashyap91@yahoo.com \\ *Corresponding author
}

\section{Madan Lal}

Department of Commerce,

Delhi School of Economics,

University of Delhi,

Delhi, India

Email: madanfms@gmail.com

\section{Sunny Makhija}

Dezan Shira \& Associates,

Delhi, India

Email: sunny.makhija@gmail.com

\begin{abstract}
This paper is an attempt to identify and understand the factors responsible for consumers' intention to hire wedding planners. Wedding planning is a combination of both tangible and intangible products such that wedding planner provides the service of managing events and purchase of related items (gifts, jewellery and dresses, etc.) on behalf of the consumer. The literature review revealed that factors like perception, motivation, attitude, trust and social pressure are responsible for consumers' intention to hire wedding planners. To study the topic, data have been accumulated from three cities, i.e. Delhi, Ludhiana and Chandigarh. The results reveal that factors like trust on wedding planners, perception towards wedding planning firms, motivation and societal pressure have significant influence on consumer's intention to hire wedding planners. Thus, this study helps in understanding the main factors responsible for diverse consumer behaviour.
\end{abstract}

Keywords: wedding planners; consumer behaviour; consumer's intention.

Reference to this paper should be made as follows: Kashyap, H., Lal, M. and Makhija, S. (2020) 'Consumers' intention to hire wedding planners: a study of selected cities in Northern India', Int. J. Financial Services Management, Vol. 10, No. 1, pp.55-76.

Biographical notes: Heena Kashyap is a Commerce Lecturer at Directorate of Education, Government of NCT. She has a teaching experience of more than five years. Her areas of interest are marketing, consumer behaviour, organisational behaviour, accounting and management. 
Madan Lal is a Senior Professor in the Department of Commerce, Delhi School of Economics. He has a teaching experience of more than 15 years. His areas of interest are managerial economics, international business, global environment management, CRM and consumer behaviour.

Sunny Makhija is a Senior Associate in the International Business Advisory team for Dezan Shira \& Associates, New Delhi office. He holds a Master's degree in Business Administration from University of Delhi. He oversees Dezan Shira \& Associates, India marketing operations and public relations along with assisting foreign companies with their India investment plans. $\mathrm{He}$ has six plus years of experience in the fields of marketing, key account management, business development and customer relationship management across IT, telecom and manufacturing industries, among others.

\section{Introduction}

Wedding industry has been one of the profitable segments among various industries. As per KPMG report, the wedding industry has a market for USD 50 billion (Nandwani, 2018). Significant amount of money is spent on wedding celebrations as it involves arrangement and coordination of many activities (Eppolito, 2019). Some people throw a lavish party due to societal pressure while others spend more money to satisfy their own desires. The pressure of society is present in both rural and urban segments of India (Bloch et al., 2004). Hectic schedules of consumers have made them more dependent on wedding planners for marriage arrangements (Liu et al., 2015). Although wedding planning is a huge and profitable business but still it has been a least discussed area in research. Business of wedding celebrations will never face a recession as weddings happen at each level and in each religion (Sengar, 2020). But this doesn't mean that wedding professionals can take risk with the quality of services as the market is flooded with numerous wedding planners (Eppolito, 2019).

Wedding planning business involves management of suppliers, employees, travel agency and other event related activities (Eppolito, 2019). This is the reason why weddings are often considered as a cumbersome and complex task. Since these weddings can raise a question on dignity and image of a consumer, it may have an intense impact on the consumer. Individuals availing the services of wedding planners can be called as "consumers" as well as "clients" (Peragine, 2008).

There are plenty of websites available on the internet that provide various options of wedding related services. Some of these websites include 'Wed Me Good', 'ShaadiSaga', 'Zank You', 'Wedding Wire', and 'ShaadiDukaan'. These websites have aggregated vendors, artists, freelancers from different places to meet a wide array of demand from consumers. These websites also help the consumers to create a separate webpage for their wedding in order to easily collate and manage all the details related to a wedding event.

\subsection{Need for the study}

The increasing numbers of wedding planners have made wedding industry very competitive (Sengar, 2020). A big question that arises is why some people hire wedding planners and why some people don't hire them. There is need to find about the 
perception and expectations that consumers hold towards these wedding planners. Also, it is imperative to investigate the main reason for popularity of wedding planners these days. There is no doubt that wedding sector has been most profitable and simultaneously a neglected sector in research, hence there is need to explore more about weddings from marketers and consumers point of view.

Many wedding companies' websites claim to provide all sort of wedding related services like venue booking, invitation cards, caterer and choreographers, etc. Thus, it is equally important to find out the most important service that a consumer expects to be performed in best possible manner by the planner. The findings will not only help in understanding consumers but would also highlight the areas for improvement in wedding companies' offerings (Liu et al., 2015). Through the study of consumer's perception, attitude, motivation and intensity of social pressure, one can make strategies to target the market. It takes a lot of time in building trust among consumers because consumers would never desire to take the risk for their most precious moment of life. Thus, there is need to study more about consumers' thoughts related to wedding planning firms.

\subsection{Objectives}

It is very important to simplify main objectives of the study as it helps in framing the structure of research (Cooper and Schindler, 2006). The objectives of this study are as follows:

1 To understand the concept of wedding management and wedding planners.

2 To identify the factors responsible for choice of wedding planners.

3 To understand the relationship between "Factors responsible for choice of wedding planner" and "consumer's intention to hire wedding planner".

\section{Review of literature}

\subsection{Consumer behaviour}

Consumer behaviour concept has provided basis for many studies. While studying consumer behaviour, many other disciplines (Psychology, Sociology and Anthropology, etc.) are also examined altogether to arrive at a decisive point (Schiffman et al., 2010). In simple terms, a consumer is a receiver who receives product or any service from the business firm. Consumer behaviour is influenced by psychological factors (motivation, perception, attitude, and learning), social factors, cultural factors and personal factors (Schiffman et al., 2010). The purchase decision of consumer is influenced by these factors. There is difference between action and intention to take an action (Wells and Prensky, 1996). A purchase of product or service displays consumer's action, whereas, merely taking a decision to buy a product or service would be an intention to take an action (Ajzen, 1985).

Hiring Intention: "Hiring intention" is intention/desire of a customer to hire wedding planner or delegate the responsibility of arranging an event to some other expert vendor. Consumer's intentions are also influenced by factors like psychological factors (motivation, perception, attitude, and learning), social factors, cultural factors and 
personal factors (Singh, 1988). The reason for the same is that "an intention leads to an action", therefore influencers shall remain identical for both intention and action (Wells and Prensky, 1996).

\subsection{Wedding planning and management}

Weddings are a temporary project for wedding firms but a permanent memory for the consumers or clients (Liu et al., 2015). Weddings are no more just a ritual instead they have become a business opportunity for many firms. Millions of rupees are spent in a luxurious weddings. Although event management is similar to wedding management on few aspects but practically there is a major difference between them. Depending upon the situation and list of activities, management is done. "Management" can be seen with a wider view as management can be done for both people and objects, thus management of different things requires different skills.

With the generation, the demands of consumers have changed, now there is trend of destination wedding, theme wedding and pre-wedding shoots too. These all new phenomena have added to the cost of weddings. Thus, this has created an unnecessary demand for those who cannot afford to bear such expenses. These weddings have been transformed into a fully-fledged business (Peragine, 2008). Plenty of information is available on websites and various physical stores are also opened in market. The problem is with the authenticity and trust because there are so many fake websites these days that one cannot rely on anyone. Apart from the budget there are many other things that bother a wedding planner, such as like, venue, number of guests and type of guests, etc.

The wedding planning websites provide services like venue bookings, decorations, caterers, photographers, videographers, make-up artists, choreographers, accommodation, music, transportation and mehendi artists, etc. (Daniels and Loveless, 2014). There are various courses available for the same. Wedding planners face issue when they have to work with a restricted budget, such that it becomes difficult for them to maintain quality and keep a close check (Liu et al., 2015). We see less advertisement of planning firms over television, rather they are more in newspapers, magazines and over internet (Wilkolaski, 2006).

Wedding Planners: Originally from year 1800 onwards, the rise of consultants started in the developed nations (Wilkolaski, 2006). Planners are the ones who hold the responsibility for making arrangements of an event. Thus, wedding planners are the ones who make arrangements for the event called "wedding". There are two kinds of planner i.e. traditional planner, referral planner and non-traditional planner. The traditional planners have link with vendors and they charge commission from bridal client. Referral planners charge commission from vendors and not from bridal client. Non-traditional planners are modern planners who charge customers on the basis of kind of service that customer has availed (Wilkolaski, 2006). These planners provide three kinds of packages i.e. small, medium and large. The smallest package starts from Rs. 400,000 and further additions increases the cost of package (Wilkolaski, 2006). There is difference between wedding consultant and wedding planner. Consultant only advices the client and responsibility of taking decisions solely rests with the client. Whereas, wedding planner does most of the job and takes most of the decisions (Wilkolaski, 2006). There are various traits that a planner must possess like self-confidence, problem solving skills and logical thinking, etc. 


\subsection{Factors influencing consumers' intention to hire wedding planners}

As earlier discussed, there are many factors that influence consumers' intention to hire wedding planners. Different researchers have quoted and studied unique variables that may be assessed while making wedding plans (Farzana and Ilayaraja, 2015). However the role of each variable /factor cannot be generalised in all the situations as different consumers have different preferences (Eppolito, 2019). Farzana and Ilayaraja (2015) found that the families of both groom and bride hold similar opinion related to booking of venue and other services. Few authors had a view that there is prominent role of groom's family in decisions related to wedding.

Only few relevant factors have been selected for the study like consumer's trust, social pressure, perception, motivation and attitude.

- Trust: Trust is a small word but has a deeper meaning. It can take years to build trust, thus consumers also prefer to avail services from those firms which are trustworthy. In the era of digitalisation, people search for online ratings and reviews before finalising any planner. However, the authenticity of online data and information cannot be verified. Since wedding is once in a lifetime moment, therefore people prefer only the experienced and renowned planners. This can also be inferred that more a consumer trusts a planner, greater will be his/her intention to avail services from that particular planner.

- Social pressure: Society has been playing a major role in determination of various aspects of society. Society influences and sometimes pressurises an individual to indulge in a certain act. Sociology and psychology are most important disciplines that are considered while studying consumer behaviour. It has been seen that social pressure is one of the reasons that forces people to spend more on wedding celebrations. The saddest part is that, the image and reputation of an individual is being decided/ judged by lavishness of the wedding event (Castillo, 2016).

- Perception: Many consumers perceive the hiring of wedding planner as a waste of money and time. Some consumers feel that they cannot do the work with perfection as they are doing business and may compromise with the quality of work. However, several consumers may be in favour of hiring wedding planners. Perception may be defined as a way one interprets the environment, thus perception towards hiring of wedding planner is an interpretation of consumers regarding wedding planners (Schiffman et al., 2010).

- Attitude: Attitude may be developed towards a person or an object. Attitude may be positive or negative such that it displays feeling of someone towards something (Schiffman et al., 2010). Attitude of consumers towards wedding planning firms or wedding planners may be positive or negative. It is important for firms that consumers develop a favourable attitude towards them (Eppolito, 2019).

- Motivation: Motivation displays a motive behind an act. Motivation may be monetary or non-monetary depending upon what motivates an individual (Wells and Prensky, 1996). Motivation behind hiring wedding planners could be to save cost and time or to satisfy esteem need by hiring professionals. 


\section{Hypotheses}

Since limited literature was available related to hiring intentions, this left many contradictory opinions. Thus following hypotheses were framed for testing:

$H_{01}$ : There is no significant relationship between Consumers' trust and Consumers' Intention to hire Wedding Planners.

$H_{02}$ : There is no significant relationship between Perception and Consumers' Intention to hire Wedding Planners.

$H_{03}$ : There is no significant relationship between Attitude and Consumers' Intention to hire Wedding Planners.

$H_{04}:$ There is no significant relationship between Motivation and Consumers' Intention to hire Wedding Planners.

$H_{05}$ : There is no significant relationship between Social pressure and Consumers' Intention to hire Wedding Planners.

$H_{06}$ : Consumers' trust doesn't mediate the relationship between Perception and Consumers' Intention to hire Wedding Planners.

$H_{07}$ : Consumers' trust doesn't mediate the relationship between Attitude and Consumers' Intention to hire Wedding Planners.

$H_{08}$ : Consumers' trust doesn't mediate the relationship between Motivation and Consumers' Intention to hire Wedding Planners.

$H_{09}$ : Consumers' trust doesn't mediate the relationship between Social pressure and Consumers' Intention to hire Wedding Planners.

$H_{10}$ : There is no significant difference in Perception, Attitude, Motivation, Social pressure, Trust and Hiring intention of consumers (towards wedding planning firms) belonging to different Age categories.

$H_{11}$ : There is no significant difference in Perception, Attitude, Motivation, Social pressure, Trust and Hiring intention of consumers (towards wedding planning firms) belonging to different Occupation categories.

$H_{12}$ : There is no significant difference in Perception, Attitude, Motivation, Social pressure, Trust and Hiring intention of consumers (towards wedding planning firms) belonging to different Education categories.

$H_{13}$ : There is no significant difference in Perception, Attitude, Motivation, Social pressure, Trust and Hiring intention of consumers (towards wedding planning firms) belonging to different Income categories.

$H_{14}$ : There is no significant difference in Perception, Attitude, Motivation, Social pressure, Trust and Hiring intention of consumers (towards wedding planning firms) belonging to different Gender categories. 


\section{Research methodology}

Research could be inductive or deductive, where inductive approach involves creation of new theory and deductive approach involves testing of an existing theory (Cooper and Schindler, 2006). For a good and realistic research it is important to understand the previous literature known as "secondary resource". To testify the existing theory there is need to collect primary data as well. To support this study, primary data has been collected through questionnaire which has been formed after elaborative study of secondary source information (literature review).

- Questionnaire: The questionnaire was divided into two sections containing 16 questions in total. The first section included questions related to demographics whereas, second part included questions related to consumer's perception, attitude, motivation, trust, intention and social pressure. All the questions were devised as "close ended" in order to avoid the misinterpretation of questions by respondents. Questions of second part were in the form of statements which were measured on 7 point Likert scale. 7 - Strongly disagree, 6 - Disagree, 5 - Somewhat disagree, 4 - Neither agree nor disagree, 3 -Somewhat agree, 2 -Agree, 1 -Strongly agree.

Table 1 Statements measuring perception, trust, attitude, motivation, social pressure and hiring intention

\begin{tabular}{ll}
\hline Factors & Statements \\
\hline Perception towards wedding & P1: Wedding firms helps in reducing the burden and pressure \\
planning firms (Liu et al., 2015) & $\begin{array}{l}\text { related to wedding. } \\
\text { P2: Wedding firms are efficient. }\end{array}$ \\
\hline
\end{tabular}

Attitude towards wedding planning firms (Kim and $\mathrm{Yu}$, 2019)

A1: Wedding planners do not pressurise clients to agree with their opinions.

A2: Wedding planners fulfil their commitments

A3: Wedding planning firms have capability to manage all the arrangements smoothly.

Motivation towards wedding planning firms

M1: Wedding planners help in managing budget of wedding.

M2: Hiring wedding planners save cost and time.

Social pressure to hire

wedding planner

(Castillo, 2016)

S1: To maintain a reputation in front of society, it is required to host a good wedding party.

S2: It is very important to invite all the relatives and friends at wedding party.

S3: Wedding has become a status symbol.

Consumer's trust on wedding planning firms (Liu et al., 2015; Peragine, 2008)

T1: Wedding planning firms are trustworthy.

T2: Wedding planning firms have trained and reliable staff.

T3: Wedding planning firms have fair charges for every service.

Intention to hire wedding planner related functions in my family.

I2: I have a strong desire to get wedding arrangements done by wedding planners whenever need arises.

Source: (Kim and Yu, 2019; Liu et al., 2015; Peragine, 2008; Castillo, 2016). 
The above statements were formed to measure their respective construct. Statements P1 and P2 measured perception of consumers/clients towards wedding planning firms. Stronger the positive perception, higher would be the chance to hire wedding planner for the wedding event. Similarly A1, A2 and A3 statements measured attitude of consumers towards wedding planners i.e. whether they hold positive attitude towards them or negative attitude towards them. A positive attitude helps in initiating an action (Schiffman et al., 2010).

Statements M1 and M2 depict the motive of consumer behind development of hiring intention towards wedding planners. Statements S1, S2 and S3 have been formulated to study the impact of social pressure on an individual or family. The aim is to assess the intensity of pressure that families exerts while deciding for wedding arrangements. T1, T2 and T3 statements measure the consumer's trust over the wedding planning firms. Lastly, I1, I2 measures intention of consumers to hire wedding planner for their marriage or wedding of their near and dear ones.

- Sample size: Collecting data from consumers all over the various cities is a tedious task therefore with the help of email, text messages and online messaging apps questionnaire was circulated. The research area was Delhi, Chandigarh and Ludhiana (few cities of northern India). The sampling method used for data collection is convenience sampling. Approximately 500 filled questionnaires were received but only 481 were considered appropriate for analysis.

The duration of data collection was 4.5 months. In order to reduce the chances of discrepancies in questionnaire, pilot testing was conducted on 55 respondents. Their suggestions were incorporated for arrival of final questionnaire. Demographic data related to Gender (male, female); Age (18-21 yrs; 22-25 yrs; 26-35 yrs; 36 yrs and above); Education (Graduate, Post graduate, Higher Secondary School (HSS) and Senior Secondary School (SSS); Occupation (Service, Business, Retired, Unemployed); Monthly family income (Rs.10,000-Rs.50,000, Rs. 50,001-Rs. 100,000, Rs. 100,001 and above) was also collected.

- Statistical tools: There are two kinds of analysis i.e. exploratory and confirmatory factor analysis. When the independent variables classification is not known, then exploratory factors analysis may be performed using SPSS software. When independent variables classification is known, then confirmatory factor analysis may be done using Smart PLS software (Hair et al., 2016). In present study Smart PLS 2.0 version and IBM SPSS 20.0 version software have been used for applying statistical tools.

\section{Analysis and results}

Firstly, details about demographics have been discussed and then all the statistical tests related to model are being presented sequence wise.

\section{Demographics}

Table 2 shows the frequency and percentage of respondents belonging to different demographic categories. Total respondents were 481 and out of which 206 respondents were from Delhi, 118 respondents were from Chandigarh and 157 respondents were from Ludhiana. The most important traits of a good wedding planner were also asked from 
respondents and it was found that consumers desires wedding planner to be a "Good listener", "Courteous" and "Practical". The reason for expecting wedding planner to be a good listener is that many times planner is not able to understand the needs of consumers (Eppolito, 2019). People also expect that the service provider should display a courteous behaviour as it may lead to communication gap. The consumer might feel uncomfortable in contacting or coordinating with the planner. Lastly, consumers would like to hire a planner who doesn't make false promises that cannot be fulfilled and practically handles every situation. There are many services (catering, venue booking, videographer, choreographer, gifts and decoration etc.) that wedding planners provide and therefore consumers were asked about most important services that they would like to obtain from wedding planning firms (Sharma and Sharma, 2015). It was found that service of catering and venue were the most important services that consumers want to avail from wedding planners. Consumers had a view that the food and venue related factors influence wedding guests. The invited guests may feel disrespected due to improper food and sitting arrangements. Therefore, the wedding planner should carefully guide consumers for finalising catering and venue for wedding related functions (Hard, 2019).

Table 2 Demographic category

\begin{tabular}{|c|c|c|}
\hline Age & Frequency & Percentage \\
\hline (18-21 yrs.) & 57 & 11.9 \\
\hline (22-25 yrs.) & 134 & 27.9 \\
\hline (26-35 yrs.) & 166 & 34.5 \\
\hline (36 yrs. and above) & 124 & 25.8 \\
\hline \multicolumn{3}{|c|}{ Gender } \\
\hline Male & 202 & 42.0 \\
\hline Female & 279 & 58.0 \\
\hline \multicolumn{3}{|c|}{ Education } \\
\hline Post-Graduation & 112 & 23.3 \\
\hline Graduation & 216 & 44.9 \\
\hline Higher Secondary School (HSS) & 94 & 19.5 \\
\hline Senior Secondary School (SSS) & 59 & 12.3 \\
\hline \multicolumn{3}{|c|}{ Occupation } \\
\hline Service & 170 & 35.3 \\
\hline Business & 147 & 30.6 \\
\hline Retired & 79 & 16.4 \\
\hline Unemployed & 85 & 17.7 \\
\hline \multicolumn{3}{|c|}{ Family monthly income } \\
\hline (Rs. $10,000-$ Rs. 50,000$)$ & 67 & 13.9 \\
\hline (Rs. 50,001-Rs. 100,000) & 147 & 30.6 \\
\hline (Rs. 100,001and above) & 267 & 55.5 \\
\hline \multicolumn{3}{|c|}{ No. of respondents from various cities } \\
\hline Delhi & 206 & 42.8 \\
\hline Chandigarh & 118 & 24.53 \\
\hline Ludhiana & 157 & 32.64 \\
\hline
\end{tabular}

Source: Primary data. 


\section{Model estimation}

The Smart PLS software allows testing of relationships between independent and dependent variables. To testify the data, maximum iterations for PLS algorithm option were fixed at 500. Whereas, to check the significance level of relationships, bootstrapping option was run on smart PLS software (Wong, 2013). Figure 1 shows the results in pictorial form, where five constructs are independent variables (Trust, Attitude, Perception, Motivation and Social pressure) and one construct is dependent variable(Intention to hire). "Trust" is measured with the help of three statements, "Attitude" is measured with the help of three statements, "Perception" is measured through two statements, "Motivation" through two statements, "Social pressure" through three statements and "hiring intention" with the help of two statements.

Figure 1 PLS path model after PLS algorithm option is run in Smart-PLS 2.0 version

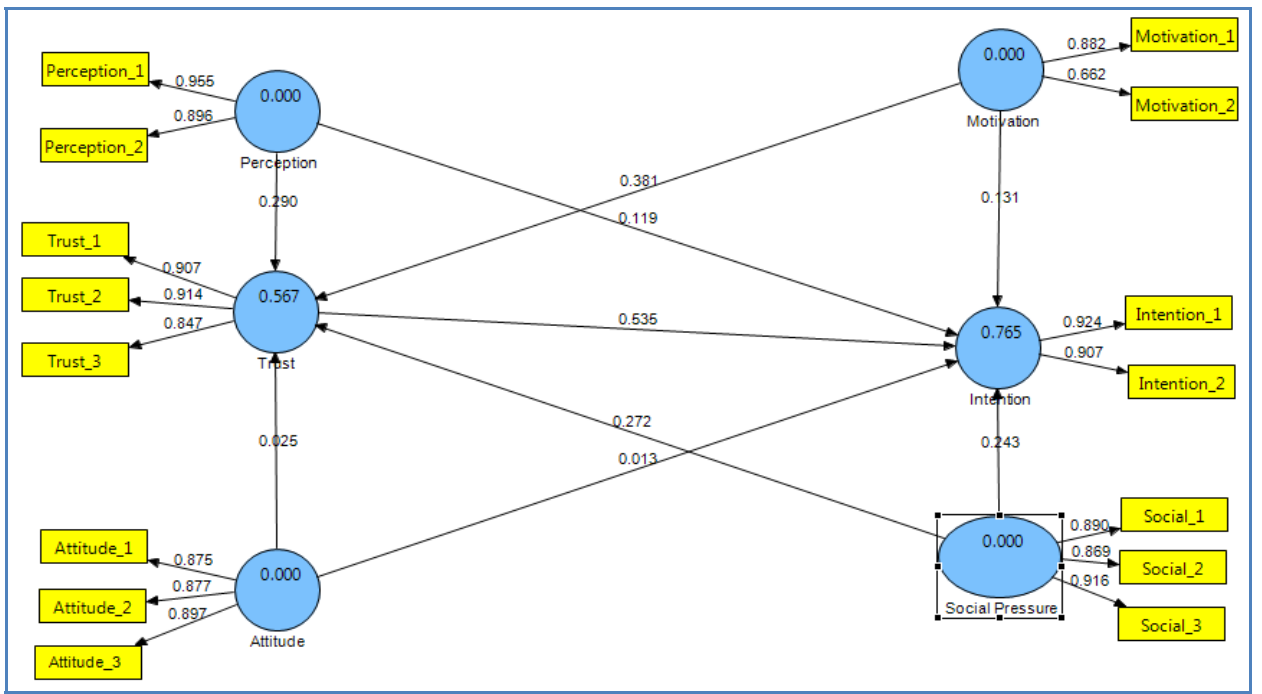

Model estimation has two steps model testing i.e. reflective model and structural model. In reflective model certain tests are conducted and on verification of those tests, structural model is further tested. If there is any discrepancy in meeting the criteria of reflective model test, then structural model testing cannot be done (Wong, 2013).

\section{Assessment of reflective measurement model}

The results of PLS algorithm are presented in Figure 1, where "Intention" to hire wedding planner is a dependent variable. Approximately $76.50 \%$ of variance is being explained through five factors namely, perception, attitude, motivation, trust and social pressure. The value displayed in "intention" construct (blue circle) represents value of $R^{2}$. Minimum acceptable $R^{2}$ value is 0.49 and in this model it is 0.765 . Thus, Explanatory power of $R^{2}$ in this case is higher which means that sufficient factors have been considered to interpret the intention of consumers towards hiring of wedding planners.

The model so formed is reflective in nature i.e. all the arrows of rectangular boxes comes from latent variable. For reflective model estimation four tests are necessary to be conducted for correct interpretation of the data. These tests are Internal consistency, 
Reliability test, Convergent validity and Discriminant validity (Hair et al., 2016). Also, the construct "Trust" has been evaluated as a mediator between other independent variables (perception, attitude, motivation and social pressure) and dependent variable (intention). It is notable that $56.7 \%$ of variance in "Trust" construct is being explained by remaining independent variables.

The Table 3 shows value of path coefficients of each path. For example: path coefficient value of path between Motivation and Intention is 0.1315 . Since all the values are positive, therefore every relationship is positive and there is no negative relationship path in the model.

Table 3 Path coefficient values

\begin{tabular}{lcc}
\hline Factors & Consumer trust & Intention \\
\hline Consumer trust & - & 0.5348 \\
Attitude & 0.025 & 0.0131 \\
Motivation & 0.3809 & 0.1315 \\
Perception & 0.29 & 0.1188 \\
Social pressure & 0.2717 & 0.2434 \\
\hline
\end{tabular}

Source: Primary data.

In order to check internal consistency, the values of composite reliability are checked which should be at least 0.70 to meet the test criteria (Hair et al., 2016) In Table 4, under composite reliability column all the values are above 0.70 , hence internal consistency test is also passed. Earlier Cronbach alpha values were considered relevant for checking internal consistency but now composite reliability is preferred for internal consistency test (Wong, 2019). As per Cronbach alpha criteria, "motivation" construct value is low i.e. near to 0.40 , but since its composite reliability value is above 0.70 therefore it will not affect the model fit (Wong, 2019).

Table 4 Convergent validity and composite reliability

\begin{tabular}{lcccc}
\hline Constructs & AVE & Composite reliability & R-Square & Cronbach alpha \\
\hline Attitude & 0.7801 & 0.9141 & - & 0.8636 \\
Intention & 0.8375 & 0.9116 & 0.7649 & 0.8064 \\
Motivation & 0.608 & 0.7525 & - & 0.3746 \\
Perception & 0.8574 & 0.9231 & - & 0.8396 \\
Social Pressure & 0.7955 & 0.921 & - & 0.8718 \\
Trust & 0.7916 & 0.9192 & 0.5675 & 0.8677 \\
\hline
\end{tabular}

Source: Primary data.

For Individual indicator reliability test, outer loadings derived from the software report are being checked. Table 5 shows the scores of individual indicators such that all the values are above threshold value i.e. 0.60 (Wong, 2019). The third test of convergent validity is conducted by comparing AVE value with threshold value. Minimum acceptable value is 0.60 and in column 2 (AVE) of Table 4 all the values are above 0.60 . Thus, convergent validity is also there. 
Table 5 Individual indicator reliability

\begin{tabular}{|c|c|c|c|c|c|c|}
\hline Scale items & Attitude & Trust & Motivation & Perception & $\begin{array}{c}\text { Social } \\
\text { pressure }\end{array}$ & Intention \\
\hline Attitude_1 & 0.8753 & & & & & \\
\hline Attitude_2 & 0.8768 & & & & & \\
\hline Attitude_3 & 0.8974 & & & & & \\
\hline Trust_1 & & 0.9067 & & & & \\
\hline Trust_2 & & 0.9141 & & & & \\
\hline Trust_3 & & 0.8468 & & & & \\
\hline Motivation_1 & & & 0.8817 & & & \\
\hline Motivation_2 & & & 0.6623 & & & \\
\hline Perception_1 & & & & 0.9546 & & \\
\hline Perception_2 & & & & 0.8964 & & \\
\hline Social_1 & & & & & 0.8899 & \\
\hline Social_2 & & & & & 0.8695 & \\
\hline Social_3 & & & & & 0.9158 & \\
\hline Intention_1 & & & & & & 0.9236 \\
\hline Intention_2 & & & & & & 0.9066 \\
\hline
\end{tabular}

Source: Primary data.

Table 6 Discriminant validity (Fornell-Larcker criteria)

\begin{tabular}{lcccccc}
\hline Factors & Attitude & Intention & Motivation & Perception & $\begin{array}{c}\text { Social } \\
\text { pressure }\end{array}$ & Trust \\
\hline Attitude & $\mathbf{0 . 8 8 3}$ & & & & & \\
Intention & 0.473 & $\mathbf{0 . 9 1 5}$ & & & & \\
Motivation & 0.189 & 0.609 & $\mathbf{0 . 7 8 0}$ & & & \\
Perception & 0.678 & 0.594 & 0.370 & $\mathbf{0 . 9 2 6}$ & & \\
Social & 0.509 & 0.673 & 0.432 & 0.459 & $\mathbf{0 . 8 9 2}$ & \\
Pressure & 0.432 & 0.831 & 0.610 & 0.573 & 0.582 & $\mathbf{0 . 8 9 0}$ \\
Trust & & & & & \\
\hline
\end{tabular}

Source: Primary data.

There are two ways to check discriminant validity i.e. cross loading method and FornellLarcker criteria. The second method i.e. Fornell-Larcker criteria is considered more relevant for checking discriminant validity (Wong, 2019). Under this criterion, square root of AVE value of each construct is being compared with latent correlation scores. In Table 6, attitude's construct $\sqrt{A V E}$ value is 0.883 which is greater than all the other values in that particular column (i.e. greater than $0.473,0.189,0.678,0.509$ and 0.432 ). Similarly for Intention construct, $\sqrt{A V E}$ value is 0.915 which is greater than other values of that particular row (i.e. $>0.473)$ and column $(>0.609,0.594,0.673$ and 0.831$)$ both. This criterion is also met as all the $\sqrt{A V E}$ values are greater than their respective row and column values. 
The above four tests are important before the assessment of structural model as in different situation the applicability of tests changes. After these tests, a small test of multi-collinearity is essential because the collinearity issue will not disclose reliable results.

\section{Multi-collinearity}

Multi-collinearity between constructs can hamper the research results, therefore it is important to identify the presence of collinearity. With the help of Variance Inflation (VIF) value it can be determined whether the two constructs are collinear with each other or not. VIF value would be less than " 5 " if there is no multi-collinearity between the constructs. The presence of collinearity depicts that all the scale items are not part of different constructs, instead belongs to a single construct (Garson, 2016). This will ruin the purpose of research and this is the reason that pilot testing and pre-testing is usually done before final survey.

In Table 7, VIF values have been calculated in two sets. In the first set "intention" is kept as dependent variable and in the second set "Trust" is kept as dependent variable. VIF values are below 5 in both the cases, therefore there is no issue of multi-collinearity between the constructs.

Table 7 Collinearity statistics

\begin{tabular}{lcccc}
\hline \multirow{2}{*}{ Factors } & \multicolumn{2}{c}{ Intention } & \multicolumn{2}{c}{ Trust } \\
\cline { 2 - 5 } & Tolerance & VIF & Tolerance & VIF \\
\hline Perception & .411 & 2.432 & .448 & 2.230 \\
Social & .563 & 1.775 & .629 & 1.591 \\
Attitude & .440 & 2.275 & .440 & 2.274 \\
Motivation & .622 & 1.607 & .747 & 1.339 \\
Trust & .465 & 2.152 & - & - \\
\hline
\end{tabular}

Source: Primary data

\section{Significance of structural model relationships}

The reports and results presented through PLS algorithm only reveals the relationship between variables but does not provide any information related to significance of the established relationships (Wong, 2019). Path coefficients values (ranges from +1 to -1 ) explain whether there is positive relationship or negative relationship between independent and dependent variable. Higher value means that there is positive relationship, whereas negative value implies a negative relationship between variables.

For significance level, $t$-statistics calculation is carried using bootstrapping option of Smart PLS software. Significance level may be checked at 1\%, 5\%, 10\% such that $t$-values for them are 2.57, 1.96 and 1.65, respectively (two-tailed tests). At 5\% significance level, relationships were tested and values are presented in Table 8. 
Table 8 Significance or $t$-statistics

\begin{tabular}{lccccc}
\hline Path & $\begin{array}{c}\text { Original } \\
\text { sample }(O)\end{array}$ & $\begin{array}{c}\text { Sample } \\
\text { mean }(M)\end{array}$ & $\begin{array}{c}\text { Standard } \\
\text { deviation } \\
(\text { STDEV })\end{array}$ & $\begin{array}{c}\text { Standard } \\
\text { error } \\
(\text { STERR) }\end{array}$ & $\begin{array}{c}\text { t-statistics } \\
(\mid \text { OSTERR })\end{array}$ \\
\hline Attitude $\rightarrow$ Intention & 0.0131 & 0.0142 & 0.0357 & 0.0357 & 0.3678 \\
Attitude $\rightarrow$ Trust & 0.025 & 0.0303 & 0.041 & 0.041 & 0.6088 \\
Motivation $\rightarrow$ Intention & 0.1315 & 0.1333 & 0.0272 & 0.0272 & 4.8349 \\
Motivation $\rightarrow$ Trust & 0.3809 & 0.3904 & 0.036 & 0.036 & 10.5695 \\
Perception $\rightarrow$ Intention & 0.1188 & 0.119 & 0.044 & 0.044 & 2.7001 \\
Perception $\rightarrow$ Trust & 0.29 & 0.2851 & 0.0395 & 0.0395 & 7.3338 \\
Social pressure $\rightarrow$ Intention & 0.2434 & 0.2423 & 0.0301 & 0.0301 & 8.0935 \\
Social pressure $\rightarrow$ Trust & 0.2717 & 0.2654 & 0.0367 & 0.0367 & 7.3956 \\
Trust $\rightarrow$ Intention & 0.5348 & 0.5327 & 0.0303 & 0.0303 & 17.6318 \\
\hline Source: Pin & & & & &
\end{tabular}

Source: Primary data; Significance $p>0.05$.

In Table 8, all the values of $t$-statistics are above 1.96 except for two paths i.e. Attitude $\rightarrow$ Trust and Attitude $\rightarrow$ Intention. This means that these two paths or relationships are not significant. Therefore hypotheses $H_{03}, H_{07}$ are accepted and hypotheses $H_{01}, H_{02}, H_{04}$, $H_{05}, H_{06}, H_{08}, H_{09}$ are not accepted. In brief, perception towards planners, motivation to hire planners, trust on wedding firms and societal pressure are the factors that affect consumer's intention to hire wedding planners. This reveals an important finding that wedding planners should focus on changing the perception of consumers towards "outsourcing of various wedding tasks" to wedding firms (Sharma and Sharma, 2015). However mediation effect of consumer's trust has also been studied. Since path of only three factors (perception, motivation and social pressure) towards trust were found significant, therefore mediation effect of only these factors was studied.

\section{Effect size $\left(F^{2}\right)$}

Effect size shows the intensity of independent variable's effect on a particular dependent variable. Larger the effect size, greater would be the intensity of independent variable to influence dependent variable. It is calculated as follows (Cohen, 1988):

$$
F^{2}=\frac{R^{2} \text { included }-R^{2} \text { excluded }}{1-R^{2} \text { included }}
$$

The effect size has been studied in two parts/ sets, where in the first set "intention" has been taken as dependent variable and in second set "trust" has been taken as dependent variable. Third column of Table 9 shows effect size of independent variables on dependent variable i.e. Intention. The results reveal that "Trust" factor affects the consumer's intention most than any other variable. However, effect size of "Attitude" is zero. This also proves that attitude towards wedding planners doesn't affect consumer's intention to hire wedding planner. Sixth column of Table 9 shows that "motivation" has greatest effect on consumer's trust than any other variable. Also, attitude does not have any effect on consumer's trust. It can be clearly inferred from the results that wedding planning firms should focus on motivating the consumers by offering them economical and average wedding packages. 
Table 9 Effect size $\left(F^{2}\right)$

\begin{tabular}{|c|c|c|c|c|c|c|}
\hline Factors & $\begin{array}{c}\text { Intention: } R^{2} \\
\text { excluded }\end{array}$ & $\begin{array}{l}\text { Effect size } \\
\text { intention }\end{array}$ & Inference & $\begin{array}{l}\text { Trust: } R^{2} \\
\text { excluded }\end{array}$ & $\begin{array}{c}\text { Effect size } \\
\text { trust }\end{array}$ & Inference \\
\hline Attitude & 0.77 & 0.00 & No effect & 0.57 & 0.00 & No effect \\
\hline Motivation & 0.75 & 0.05 & $\begin{array}{l}\text { Small to } \\
\text { medium }\end{array}$ & 0.46 & 0.20 & Medium \\
\hline Perception & 0.76 & 0.02 & $\begin{array}{l}\text { Small to } \\
\text { medium }\end{array}$ & 0.53 & 0.08 & $\begin{array}{l}\text { Small to } \\
\text { medium }\end{array}$ \\
\hline $\begin{array}{l}\text { Social } \\
\text { Pressure }\end{array}$ & 0.73 & 0.12 & $\begin{array}{l}\text { Small to } \\
\text { medium }\end{array}$ & 0.52 & 0.09 & $\begin{array}{l}\text { Small to } \\
\text { medium }\end{array}$ \\
\hline Trust & 0.64 & 0.35 & Medium to large & & - & - \\
\hline
\end{tabular}

Source: Primary data.

Predictive relevance $\left(Q^{2}\right)$

Predictive relevance determines the accuracy of model i.e. whether the model is able to predict what it is expected to predict or not (Hair et al., 2016). It is calculated as follows:

$$
Q^{2}=1-\frac{S S E}{S S O}
$$

where SSE = Sum of squared prediction errors; SSO = Sum of squared observations

The value of $Q^{2}$ should be greater than " 0 " for meeting the predictive relevance of model (Hair et al., 2016). However, a value closer to " 1 " indicates that the model is realistic and is free from errors. In Table 10 all the values are greater than zero; therefore model has good predictive relevance and is accurate. The results have assured that factors that were incorporated in the model are imperative to predict consumer behaviour in wedding industry.

Table 10 Cross-validity redundancy value

\begin{tabular}{lccc}
\hline Construct & SSO & SSE & $1-S S E / S S O$ \\
\hline Intention & 962 & 393 & 0.592 \\
Trust & 1443 & 796 & 0.449 \\
\hline
\end{tabular}

Source: Primary data.

Mediation effect

Mediation effect is an effect where intervention of a third variable changes the relationship between dependent variable and independent variable (Wong, 2019). Before testing mediation effect it is important that there is significant relationship between independent variable and mediator. Since "Attitude" (independent) does not have any significant relationship with the mediator and dependent variable, therefore its mediation effect is not studied.

The mediation effect has been studied with the help of VAF value which is calculated by dividing indirect effect with total effect (see Table 11). If the value is below 0.20 , then there is no mediation, if value is between 0.20 and 0.80 , then mediation effect is partial and if value is above 0.80 then mediation effect is full (Hair et al., 2009). Table-11 shows that consumer trust acts as a partial mediator between dependent variable and independent variables. This also means that the intention of consumers to hire wedding planner is not solely dependent on trust, instead it is also dependent on many other factors like perception, motivation and social pressure. 
Table 11 Mediation effect

\begin{tabular}{|c|c|c|c|c|c|c|c|}
\hline Path & $\begin{array}{c}\text { Direct } \\
\text { effect }\end{array}$ & $a^{*}$ & $b^{*}$ & $\begin{array}{c}\text { Indirect } \\
\text { effect }\left(a^{*} b\right)\end{array}$ & $\begin{array}{l}\text { Total } \\
\text { effect }\end{array}$ & $V A F$ & $\begin{array}{c}\text { Mediation } \\
\text { type }\end{array}$ \\
\hline Motivation $\rightarrow$ Intention & 0.162 & 0.610 & 0.738 & 0.450 & 0.612 & 0.735 & Partial \\
\hline Perception $\rightarrow$ Intention & 0.174 & 0.574 & 0.731 & 0.420 & 0.594 & 0.707 & Partial \\
\hline Social Pressure $\rightarrow$ Intention & 0.283 & 0.582 & 0.669 & 0.389 & 0.672 & 0.579 & Partial \\
\hline
\end{tabular}

Source: Primary data; Significance $p>0.05$; "a" = independent variable $\rightarrow$ mediator and " $b "=$ mediator $\rightarrow$ dependent variable*.

\section{Multi-group analysis}

There is no direct way to conduct multi-group analysis for categorical data in Smart PLS software. Therefore, IBM SPSS version 20.0 has been used to perform Tukey HSD test on categorical data. Tukey HSD test helps in knowing the differences between various categories of a particular factor/demographic. The results of Tukey HSD test on various demographics are as follows:

\section{Age}

Table 12 shows result of only those variables whose significance value was less than 0.05 . Except for perception and attitude variable, all other variables have significant values i.e. $p<0.05$. This means that there is difference in the level of motivation, trust, social influence and intention among consumers of different age categories. Tukey HSD test reveals the exact difference across various categories. Respondents of age category "36 yrs. and above" have greater trust (on wedding planners) and intention to hire wedding planners than other category respondents. The test also revealed that people exceeding the age of 36 years exerts more social pressure than lower aged individuals. The reason for this difference is generation gap and change in opinion of young individuals. The level of motivation was found higher among respondents of age category "36 yrs. and above" than other categories. Respondents of age category 18-21 yrs. were found to have lowest motivation, trust, social influence and intention to hire wedding planner. This is an alarming situation for wedding firms because they should start devising strategies to encourage and persuade young individuals as well.

Table 12 Tukey HSD for AGE category

\begin{tabular}{|c|c|c|c|c|c|c|c|}
\hline \multirow[b]{2}{*}{$\begin{array}{l}\text { Dependent } \\
\text { variable }\end{array}$} & \multirow[b]{2}{*}{$I$} & \multirow[b]{2}{*}{$J$} & \multirow[b]{2}{*}{$\begin{array}{c}\text { Mean } \\
\text { difference (I-J) }\end{array}$} & \multirow[b]{2}{*}{$\begin{array}{l}\text { Std. } \\
\text { error }\end{array}$} & \multirow[b]{2}{*}{ Sig. } & \multicolumn{2}{|c|}{$\begin{array}{c}95 \% \\
\text { Confidence } \\
\text { Interval }\end{array}$} \\
\hline & & & & & & $\begin{array}{l}\text { Lower } \\
\text { bound }\end{array}$ & $\begin{array}{l}\text { Upper } \\
\text { bound }\end{array}$ \\
\hline \multirow{8}{*}{ Social } & \multirow{2}{*}{ (26-35 yrs.) } & (22-25 yrs.) & $-.40328^{*}$ & .094 & .000 & -.647 & -.160 \\
\hline & & (18-21 yrs.) & $-.47206^{*}$ & .125 & .001 & -.794 & -.150 \\
\hline & \multirow{2}{*}{$\begin{array}{c}(36 \text { yrs. and } \\
\text { above) }\end{array}$} & (22-25 yrs.) & $-.38505^{*}$ & .101 & .001 & -.646 & -.124 \\
\hline & & (18-21 yrs.) & $-.45383^{*}$ & .130 & .003 & -.790 & -.118 \\
\hline & \multirow{2}{*}{ (22-25 yrs.) } & (26-35 yrs.) & $.40328^{*}$ & .094 & .000 & .160 & .647 \\
\hline & & (36 yrs. and above) & $.38505^{*}$ & .101 & .001 & .124 & .646 \\
\hline & \multirow{2}{*}{ (18-21 yrs.) } & (26-35 yrs.) & $.47206^{*}$ & .125 & .001 & .150 & .794 \\
\hline & & (36 yrs. and above) & $.45383^{*}$ & .130 & .003 & .118 & .790 \\
\hline
\end{tabular}


Table 12 Tukey HSD for AGE category (continued)

\begin{tabular}{|c|c|c|c|c|c|c|c|}
\hline \multirow[b]{2}{*}{$\begin{array}{l}\text { Dependent } \\
\text { variable }\end{array}$} & \multirow[b]{2}{*}{$I$} & \multirow[b]{2}{*}{$J$} & \multirow[b]{2}{*}{$\begin{array}{c}\text { Mean } \\
\text { difference }(I-J)\end{array}$} & \multirow[b]{2}{*}{$\begin{array}{l}\text { Std. } \\
\text { error }\end{array}$} & \multirow[b]{2}{*}{ Sig. } & \multicolumn{2}{|c|}{$\begin{array}{c}95 \% \\
\text { Confidence } \\
\text { Interval }\end{array}$} \\
\hline & & & & & & $\begin{array}{l}\text { Lower } \\
\text { bound }\end{array}$ & $\begin{array}{l}\text { Upper } \\
\text { bound }\end{array}$ \\
\hline \multirow{8}{*}{ Trust } & \multirow{2}{*}{ (26-35 yrs.) } & (22-25 yrs.) & $-.30046^{*}$ & .100 & .015 & -.558 & -.043 \\
\hline & & (18-21 yrs.) & $-.55672^{*}$ & .132 & .000 & -.897 & -.216 \\
\hline & \multirow{2}{*}{$\begin{array}{c}\text { (36 yrs. and } \\
\text { above) }\end{array}$} & (22-25 yrs.) & $-.28812^{*}$ & .107 & .037 & -.564 & -.012 \\
\hline & & (18-21 yrs.) & $-.54438^{*}$ & .138 & .001 & -.899 & -.190 \\
\hline & \multirow{2}{*}{ (22-25 yrs.) } & $(26-35$ yrs. $)$ & $.30046^{*}$ & .100 & .015 & .043 & .558 \\
\hline & & ( 36 yrs. and above) & $.28812^{*}$ & .107 & .037 & .012 & .564 \\
\hline & \multirow{2}{*}{ (18-21 yrs.) } & (26-35 yrs.) & $.55672^{*}$ & .132 & .000 & .216 & .897 \\
\hline & & (36 yrs. and above) & $.54438^{*}$ & .138 & .001 & .190 & .899 \\
\hline \multirow{8}{*}{ Intention } & \multirow[b]{2}{*}{ (26-35 yrs.) } & (22-25 yrs.) & $-.30417^{*}$ & .117 & .046 & -.605 & -.003 \\
\hline & & (18-21 yrs.) & $-.61499^{*}$ & .154 & .000 & $\begin{array}{c}- \\
1.013\end{array}$ & -.217 \\
\hline & \multirow{2}{*}{$\begin{array}{l}\text { (36 yrs. and } \\
\text { above) }\end{array}$} & (22-25 yrs.) & $-.40955^{*}$ & .125 & .006 & -.732 & -.087 \\
\hline & & (18-21 yrs.) & $-.72036^{*}$ & .161 & .000 & $\begin{array}{c}- \\
1.135\end{array}$ & -.306 \\
\hline & \multirow{2}{*}{ (22-25 yrs.) } & (26-35 yrs.) & $.30417^{*}$ & .117 & .046 & .003 & .605 \\
\hline & & (36 yrs. and above) & $.40955^{*}$ & .125 & .006 & .087 & .732 \\
\hline & \multirow{2}{*}{ (18-21 yrs.) } & $(26-35$ yrs. $)$ & $.61499^{*}$ & .154 & .000 & .217 & 1.013 \\
\hline & & (36 yrs. and above) & $.72036^{*}$ & .161 & .000 & .306 & 1.135 \\
\hline \multirow{10}{*}{ Motivation } & \multirow[b]{2}{*}{ (26-35 yrs.) } & (22-25 yrs.) & $-.49667^{*}$ & .118 & .000 & -.800 & -.193 \\
\hline & & (18-21 yrs.) & $-.92237^{*}$ & .156 & .000 & $1 . \overline{324}$ & -.521 \\
\hline & \multirow{2}{*}{$\begin{array}{l}\text { (36 yrs. and } \\
\text { above) }\end{array}$} & (22-25 yrs.) & $-.57649^{*}$ & .126 & .000 & -.902 & -.251 \\
\hline & & (18-21 yrs.) & $-1.00219^{*}$ & .162 & .000 & $\begin{array}{c}- \\
1.420\end{array}$ & -.584 \\
\hline & \multirow{4}{*}{ (22-25 yrs.) } & (26-35 yrs.) & $.49667^{*}$ & .118 & .000 & .193 & .800 \\
\hline & & (36 yrs. and above) & $.57649^{*}$ & .126 & .000 & .251 & .902 \\
\hline & & (18-21 yrs.) & $-.42570^{*}$ & .160 & .041 & -.839 & -.012 \\
\hline & & (26-35 yrs.) & $.92237^{*}$ & .156 & .000 & .521 & 1.324 \\
\hline & \multirow[t]{2}{*}{ (18-21 yrs.) } & (36 yrs. and above) & $1.00219^{*}$ & .162 & .000 & .584 & 1.420 \\
\hline & & (22-25 yrs.) & $.42570^{*}$ & .160 & .041 & .012 & .839 \\
\hline
\end{tabular}

Source: Primary data; *. The mean difference is significant at the 0.05 level.

Table 13 presents summary of multi-group analysis. Since result for categories of education, occupation, income and gender were insignificant, therefore hypotheses $H_{11}$, $H_{12}, H_{13}$ and $H_{14}$ were accepted. However hypothesis $H_{10}$ was not accepted because results were found to be significant for different age categories. 
Table 13 Summary of multi-group analysis

\begin{tabular}{lll}
\hline Category & Result & Summary \\
\hline Age & Significant & $\begin{array}{l}\text { There is difference in the level of motivation, trust, social } \\
\text { influence and intention among consumers of different age } \\
\text { categories. Respondents of age category "18-21" yrs. were } \\
\text { found to have lowest motivation, trust, social influence and } \\
\text { intention to hire wedding planner. Whereas, age category } \\
\text { "36 yrs. and above" were found to have most positive } \\
\text { approach towards these factors. }\end{array}$ \\
\hline Education & Insignificant & $\begin{array}{l}\text { Respondents from different educational background do not } \\
\text { posses different view on perception, attitude, motivation, } \\
\text { trust, social pressure and intention to hire wedding planner. }\end{array}$ \\
\hline Occupation & Insignificant & $\begin{array}{l}\text { Respondents belonging to service class, business class, } \\
\text { unemployment class and retired class have no different view } \\
\text { on perception, attitude, motivation, trust, social pressure and } \\
\text { intention to hire wedding planner. }\end{array}$ \\
\hline Income & Insignificant & $\begin{array}{l}\text { Respondents from different income categories do not have } \\
\text { different view on perception, attitude, motivation, trust, } \\
\text { social pressure and intention to hire wedding planner. }\end{array}$ \\
\hline Gender & Insignificant & $\begin{array}{l}\text { Males and females do not have different view on perception, } \\
\text { attitude, motivation, trust, social pressure and intention to } \\
\text { hire wedding planner. }\end{array}$ \\
\hline
\end{tabular}

Source: Primary data

\section{Hypotheses testing}

Table 14 presents the summary of hypotheses, where six hypotheses were accepted $\left(H_{03}, H_{07}, H_{11}, H_{12}, H_{13}\right.$ and $\left.H_{14}\right)$ and eight hypotheses $\left(H_{01}, H_{02}, H_{04}, H_{05}, H_{06}, H_{08}, H_{09}\right.$ and $\left.H_{10}\right)$ were not accepted. This research has revealed many important aspects related to consumer behaviour. On the basis of result, wedding firms can start devising unique strategy for different age segments.

Table 14 Hypotheses testing results

\begin{tabular}{lll}
\hline & Hypotheses & Accepted/Rejected \\
\hline$H_{01}$ & $\begin{array}{l}\text { There is no significant relationship between consumers' trust and } \\
\text { consumers' intention to hire wedding planners. }\end{array}$ & Not Accepted \\
\hline$H_{02}$ & $\begin{array}{l}\text { There is no significant relationship between perception and } \\
\text { consumers' intention to hire wedding planners. }\end{array}$ & Not Accepted \\
\hline$H_{03}$ & $\begin{array}{l}\text { There is no significant relationship between attitude and } \\
\text { consumers' intention to hire wedding planners. }\end{array}$ & Accepted \\
\hline$H_{04}$ & $\begin{array}{l}\text { There is no significant relationship between motivation and } \\
\text { consumers' intention to hire wedding planners. }\end{array}$ & Not Accepted \\
\hline$H_{05}$ & $\begin{array}{l}\text { There is no significant relationship between social pressure and } \\
\text { consumers' intention to hire wedding planners. }\end{array}$ & Not Accepted \\
\hline$H_{06}$ & $\begin{array}{l}\text { Consumers trust doesn't mediate the relationship between } \\
\text { perception and consumers' intention to hire wedding planners. }\end{array}$ & Not Accepted \\
\hline$H_{07}$ & $\begin{array}{l}\text { Consumers trust doesn't mediate the relationship between attitude } \\
\text { and consumers' intention to hire wedding planners. }\end{array}$ & Accepted \\
\hline
\end{tabular}


Table 14 Hypotheses testing results (continued)

\begin{tabular}{|c|c|c|}
\hline & Hypotheses & Accepted/Rejected \\
\hline$H_{08}$ & $\begin{array}{l}\text { Consumers trust doesn't mediate the relationship between } \\
\text { motivation and consumers' intention to hire wedding planners. }\end{array}$ & Not Accepted \\
\hline$H_{09}$ & $\begin{array}{l}\text { Consumers trust doesn't mediate the relationship between social } \\
\text { pressure and consumers' intention to hire wedding planners. }\end{array}$ & Not Accepted \\
\hline$H_{10}$ & $\begin{array}{l}\text { There is no significant difference in perception, attitude, } \\
\text { motivation, social pressure, trust and intention of consumers } \\
\text { (towards wedding planning firms) belonging to different age } \\
\text { categories. }\end{array}$ & Not Accepted \\
\hline$H_{11}$ & $\begin{array}{l}\text { There is no significant difference in perception, attitude, } \\
\text { motivation, social pressure, trust and intention of consumers } \\
\text { (towards wedding planning firms) belonging to different } \\
\text { occupation categories. }\end{array}$ & Accepted \\
\hline$H_{12}$ & $\begin{array}{l}\text { There is no significant difference in perception, attitude, } \\
\text { motivation, social pressure, trust and intention of consumers } \\
\text { (towards wedding planning firms) belonging to different } \\
\text { education categories. }\end{array}$ & Accepted \\
\hline$H_{13}$ & $\begin{array}{l}\text { There is no significant difference in perception, attitude, } \\
\text { motivation, social pressure, trust and intention of consumers } \\
\text { (towards wedding planning firms) belonging to different income } \\
\text { categories. }\end{array}$ & Accepted \\
\hline$H_{14}$ & $\begin{array}{l}\text { There is no significant difference in perception, attitude, } \\
\text { motivation, social pressure, trust and intention of consumers } \\
\text { (towards wedding planning firms) belonging to different gender } \\
\text { categories. }\end{array}$ & Accepted \\
\hline
\end{tabular}

Source: Primary data.

\section{Findings}

The aim of study was to understand the factors responsible for creating hiring intentions (related to wedding planners) among consumers. Total numbers of respondents were 481, out of which 202 were males and 279 were females. While evaluating the traits of a good wedding planner, it was found that consumers' desires wedding planner to be a good listener, courteous and practical. The most important service on which consumers did not want to compromise were related to catering and venue arrangements. Intention to hire wedding planner is a dependent variable in this study. It was found that $76.50 \%$ of variance was explained through five factors namely, perception, attitude, motivation, trust and social pressure. This can be also be interpreted that sufficient factors have been considered to interpret the intention of consumers towards hiring of wedding planners.

The two relationships were found to be insignificant i.e. Attitude $\rightarrow$ Trust and Attitude $\rightarrow$ Intention. Therefore hypotheses $H_{03}, H_{07}$ were accepted and $H_{01}, H_{02}, H_{04}, H_{05}$, $H_{06}, H_{08}, H_{09}$ were not accepted. The results reveal that "Trust" factor affects the consumer's intention more than any other variable does. However, it was found that attitude towards wedding planners doesn't affect consumer's intention to hire wedding planner. The predictive relevance of model was also checked and verified. While 
evaluating mediation effect, it was found that consumer's trust acts as a partial mediator between three independent variables (perception, motivation and social pressure) and one dependent variable.

While performing multi-group analysis for demographic categories, it was found that the results related to categories of occupation, education, income and gender were insignificant. However, significant differences were found across different age categories. Respondents of age category " 36 yrs. and above" were found to have greater trust (on wedding planners) and intention to hire wedding planners than other category respondents. The tests also reveal that people exceeding the age of 36 years exerts more social pressure than lower aged individuals. The level of motivation was found highest among respondents of age category " 36 yrs. and above". Respondents of age category 18-21 yrs. were found to have lowest motivation, trust, social influence and intention to hire wedding planner. Thus hypotheses $H_{11}, H_{12}, H_{13}$ and $H_{14}$ were accepted and $H_{10}$ was not accepted.

\section{Limitations}

The research has certain limitations which would provide scope for further study. There are a few pitfalls that can be assessed in future:-

- Owing to the inability to reach various parts of the nation, respondents have been targeted from three cities only i.e. Delhi, Chandigarh, Ludhiana. Although the results may not be able to reach a generalisation stage, they have provided relevant and helpful information related to consumers.

- There is need to explore more factors responsible for instigating consumers to hire wedding planners. Since attitude factor showed an insignificant relationship with consumer's intention, there may be chances that some other statements can better measure the construct.

- Apart from "consumer's Trust", there could have been any other mediator as well. With the help of Exploratory Factor Analysis (EFA) and more rigorous review of literature more mediators may be tested.

- There is need to understand the expectations of wedding planners as well i.e. understanding view point of wedding planners as well as consumers.

\section{Conclusions}

Wedding industry had been flourishing since ages, but its existence has now become prominent. Hiring wedding planners is a hassle free task. Some consumers are ready to host an event even if it is beyond their budget. Therefore, it becomes important to understand the expectations of consumers. In last minute rush, consumers/clients are ready to sacrifice their dreams and demands, but there is need to figure out actual expectations of consumers (Eppolito, 2019). The study has focused on main factors that interplay a crucial role in decision making of consumers while hiring a wedding planner. There is need to change the perception and build trust among consumers for sustenance 
of companies in the market. Wedding industry is flushed with numerous suppliers, vendors and planners which make it a more complex industry.

There is no replacement for a one time memory of tying a knot with the partner. Consumers are afraid because they know that even basic things would be scrutinised by the guests in a wedding. Thus, it is important for consumers also to express truly about their feelings and expectations. The results have shown that constant social pressure is affecting the intention of people to hire professionals for wedding arrangements. This also reflects a bad face of society where many people are indirectly forced to go beyond their affordability to please the society. Thus, wedding planners holds a bigger responsibility of devising strategies that are profitable for them but could also help consumers in dealing with social pressure. The research has provided a direction for wedding planners, where the consumers' trust can be won by changing their perception. Consumers shall be motivated to hire wedding planners through offerings that could meet their budget and minimise impact of social pressure over them. Wedding planners should think about innovations to replace expensive services with cost effective services.

\section{References}

Ajzen, I. (1985) 'From intentions to actions: a theory of planned behavior', in Kuhl, J. and Beckmann, J. (Eds): Action Control, Springer, Berlin, Heidelberg, pp.11-39.

Bloch, F., Rao, V. and Desai, S. (2004) 'Wedding celebrations as conspicuous consumption: signaling social status in Rural India', The Journal of Human Resources, Vol. 39, No. 3, pp.675-695.

Castillo, M. (2016) Blame social media for the rising cost of weddings. Available online at: https://www.cnbc.com/2016/05/12/blame-social-media-for-the-rising-cost-of-weddings.html (accessed on 1 April 2020).

Cohen, J. (1988) Statistical Power Analysis for the Behavioural Sciences, 2nd ed., Lawrence Erlbaum Associates, USA.

Cooper, D. and Schindler, P. (2006) Business Research Methods, McGraw Hill Education.

Daniels, M. and Loveless, C. (2014). Wedding planning and Management: Consultancy for diverse clients, 2nd ed., Routledge, Oxon.

Eppolito, A. (2019) Redefine Your Wedding Business: Create the Business You Want Wherever You Are, BOOKBABY.

Farzana, R.J. and Ilayaraja, D. (2015) 'Decision making of consumers in the consumption of wedding services with special reference to Femina hotel', International Journal of Management, Vol. 6, No. 1, pp.46-58.

Garson, G.D. (2016) Partial Least Squares (PLS-SEM), G. David Garson and Statistical Associates Publishing, USA.

Hair, J.F., Black, W.C., Babin, B.J. and Anderson, R.E. (2009) Multivariate Data Analysis, 7th ed., Pearson, USA.

Hair, J.F., Hult, G.T., Ringle, C. and Sarstedt, M. (2016) A Primer on Partial Least Squares Structural Equation Modelling (PLS-SEM), 2nd ed., Sage Publications.

Hard, R. (2019) How an event planner works with a caterer. Available online at: https://www.thebalancesmb.com/catering-for-event-planners-1223641 (accessed on 30 May 2020).

Kim, H.J. and Yu, J. (2019) 'Development of a scale for the selection criteria of wedding planners', The Research Journal of the Costume Culture, Vol. 27, No. 4, pp.323-335. 
Liu, H.C., Jing, P.H. and Chiu, Y.Y. (2015) 'Investigating wedding quality characteristics: evidence from Kaohsiung', Journal of Tourism, Heritage and Services Marketing, Vol. 1, No. 1, pp.10-15.

Nandwani, D. (2018) The recession-proof big fast Indian wedding just got more corporatised. Available online at: https://www.cnbctv18.com/retail/the-recession-proof-big-fast-indianwedding-just-got-more-corporatised-1012991.htm (accessed on 2 April 2020).

Peragine, J.N. (2008) How to Open and Operate a Financially Successful Wedding Consultant and Planning Business, Atlantic Publishing Company, Florida.

Schiffman, L.G., Kanuk, L.L. and Wisenblit, J. (2010) Consumer Behavior, 10th, ed., Prentice Hall, Boston, London.

Sengar, N.S. (2020) Wedding planning a recession free industry: Mahesh Shirodkar of Tamarind Global. Available online at: https://brandequity.economictimes.indiatimes.com/news/ business-of-brands/wedding-planning-a-recession-free-industry-mahesh-shirodkar-oftamarind-global/73039118 (accessed on 1 April 2020).

Sharma, S. and Sharma, A. (2015) 'New emerging and rising trends in North Indian wedding in India', HCTL Open International Journal of Technology Innovations and Research, Vol. 14, pp.1-13.

Singh, J. (1988) 'Consumer complaint intentions and behavior: definitional and taxonomical issues', Journal of Marketing, Vol. 52, No. 1, pp.93-107.

Wells, W.D. and Prensky, D. (1996) Consumer Behavior, Wiley, New York.

Wilkolaski, S. (2006) How to Start a Wedding Planning Business, Garnet Press, Self Published Marketing Group.

Wong, K.K-K. (2013) 'Partial least squares structural equation modeling (PLS-SEM) techniques using SmartPLS', Marketing Bulletin, Vol. 24, pp.1-32.

Wong, K.K. (2019) Mastering Partial Least Squares Structural Equation Modeling (Pls-Sem) with Smartpls in 38 Hours, iUniverse, Bloomington. 